\title{
ANALYSIS OF THE CORRELATION BETWEEN THE COMPANIES' INVESTMENT IN RESEARCH, DEVELOPMENT AND PROFITABILITY, AND THE COUNTRIES' COMPETITIVENESS AND INNOVATION CAPABILITY
}

\section{ANÁLISE DA RELAÇÃO ENTRE INVESTIMENTOS EM PESQUISA E DESENVOLVIMENTO E RENTABILIDADE DAS EMPRESAS COM A COMPETITIVIDADE E CAPACIDADE DE INOVAÇÃO DOS PAÍSES}

\section{ANÁLISIS DE LA RELACIÓN ENTRE LAS INVERSIONES EN INVESTIGACIÓN Y DESARROLLO Y LA RENTABILIDAD DE LAS EMPRESAS CON LA CAPACIDAD DE COMPETITIVIDAD E INNOVACIÓN DE LOS PAÍSES}

Ana Lucia Brenner Barreto Miranda

Doutoranda em Administração pela Universidade Potiguar (UNP/RN). Professora efetiva da

Universidade Federal Rural do Semi-Árido (UFERSA)

analuciabrenner@yahoo.com.br

https://orcid.org/0000-0001-7239-1299

Cristine Hermann Nodari,

Pós-Doutorado em Inovação pelo Programa Nacional de Pós-Doutorado da Coordenação de Aperfeiçoamento de Pessoal de Nível Superior (PNPD/CAPES). Doutora em Administração pela Pontifícia Universidade Católica do Rio Grande do Sul -PUCRS

cristine.nodari@gmail.com

https://orcid.org/0000-0003-0397-337X

Liana Holanda Nepomuceno Nobre

Doutorado em Administração pela Pontifícia Universidade Católica do Paraná, Brasil. Professora Adjunta da Universidade Federal Rural do Semiárido (UFERSA)

liananobre@ufersa.edu.br

https://orcid.org/0000-0001-6756-9179

Serje Schmidt

Doutor em Economía de L'empresa pela Universitat de Les Illes Balears, Espanha e doutorado em Administração na UNISINOS, Brasil. Professor titular do Mestrado Acadêmico em Administração da Universidade Feevale

serje@feevale.br

https://orcid.org/0000-0002-5710-1828

Editor Científico: José Edson Lara

Organização Comitê Científico

Double Blind Review pelo SEER/OJS

Recebido em 14.05.2020

Aprovado em 03.08.2020

Este trabalho foi licenciado com uma Licença Creative Commons - Atribuição - Não Comercial 3.0 Brasil 

capability

\begin{abstract}
Objective: This study aims to analyze the relationship between the percentage of investment in $R \& D$ and the percentage of profitability of companies with the competitiveness and innovation capacity of the countries, aiming to identify whether the companies that invest the most in R\&D and the most profitable are located in countries with the highest levels of competitiveness and innovative capacity.
\end{abstract}

Methodology/Approach: The $\mathrm{R} \& \mathrm{D}$ investment and company profitability indices were extracted from the EU Industrial R\&D Investment Scoreboard, 2018 edition; and for the competitiveness and innovation capacity scores of the countries, the Global Competitiveness Report 2018 was used. The relationships between the variables were analyzed using: i) twoway ANOVA to examine the influence of two different categorical independent variables; ii) Tukey's post-hoc test, to identify the location of significant differentials. Four hypotheses were raised to analyze the relationships of interest.

Originality / Relevance: The findings of this study contradict some studies that stated that innovations in companies contribute to the development of the countries that are located.

Results: After applying ANOVA to the relationships, it was found that none of the relationships were statistically significant.

Theoretical / methodological contributions: The findings of this study demonstrated that the companies that invest the most in R\&D and the most profitable ones are not necessarily located in the most competitive countries with the greatest capacity for innovation.

Keywords: Research and Development; Competitiveness; Innovation; Profitability.

\title{
Resumo
}

Objetivo: Este estudo tem como objetivo analisar a relação entre percentual de investimento em P\&D e percentual de rentabilidade das empresas com os escores de competitividade e capacidade de inovação dos países, visando identificar se as empresas que mais investem em P\&D e as mais rentáveis estão situadas em países com os mais altos níveis de competitividade e de capacidade de inovação.

Metodologia/Abordagem: Os índices de investimentos em P\&D e de rentabilidade das empresas foram extraídos do EU Industrial $R \& D$ Investment Scoreboard, edição de 2018; e para os escores da competitividade e capacidade de inovação dos países fez uso do Global Competitiveness Report 2018. As relações entre as variáveis foram analisadas utilizando: i) ANOVA two-way para examinar a influência de duas variáveis independentes categóricas diferentes; ii) teste post-hoc de Tukey, para identificar a localização dos diferenciais significativos. Foram levantadas quatro hipóteses para analisar as relações de interesse.

Originalidade/Relevância: Os achados deste estudo contradizem alguns estudos que afirmaram que as inovações nas empresas contribuem para o desenvolvimento dos países que estão localizadas.

Principais resultados: Após a aplicação da ANOVA nas relações, identificou-se que nenhuma das relações foram estatisticamente significativas. 
Contribuições teóricas/metodológicas: Os achados deste estudo demonstraram que as empresas que mais investem em $\mathrm{P} \& \mathrm{D}$ e as mais rentáveis não necessariamente estão situadas nos países mais competitivos e com maior capacidade de inovação.

Palavras-chave: Pesquisa e Desenvolvimento; Competitividade; Inovação; Rentabilidade.

\section{Resumen}

Objetivo: Este estudio tiene como objetivo analizar la relación entre el porcentaje de inversión en I + D y el porcentaje de rentabilidad de las empresas con la capacidad de competitividad e innovación de los países, con el objetivo de identificar si las empresas que más invierten en I + D y las más rentables están ubicados en países con los más altos niveles de competitividad y capacidad innovadora.

Metodología/Enfoque: Los índices de inversión en I + D y rentabilidad de la empresa se extrajeron del Cuadro de indicadores de inversión en I + D industrial de la UE, edición 2018; y para los puntajes de competitividad y capacidad de innovación de los países, se utilizó el Informe de Competitividad Global 2018. Las relaciones entre las variables se analizaron usando: i) ANOVA bidireccional para examinar la influéncia de dos variables independientes categóricas diferentes; ii) Prueba post-hoc de Tukey, para identificar la ubicación de diferenciales significativos. Se plantearon cuatro hipótesis para analizar las relaciones de interés.

Originalidad//Relevancia: Los resultados de este estudio contradicen algunos estudios que afirman que las innovaciones en las empresas contribuyen al desarrollo de los países que se encuentran.

Resultados principales: Después de aplicar ANOVA a las relaciones, se descubrió que ninguna de las relaciones era estadísticamente significativa.

Contribuciones teóricas / metodológicas: los resultados de este estudio demostraron que las empresas que más invierten en I + D y las más rentables no se encuentran necesariamente en los países más competitivos con mayor capacidad de innovación.

Palabras clave: Investigación y desarrollo; Competitividad; Innovación; Rentabilidad.

\section{Introduction}

For companies to improve their innovation capabilities in their organizational routines, they need to be inter-related so that they develop new products and processes. As stated by Peng, Schroeder and Shah (2008), the companies that innovate are of fundamental importance for the country to reach good levels of competitiveness. Therefore, the country must provide circumstances so that their companies may invest in research and development (R\&D). Actually, innovative companies do so. Investing in R\&D increases the company's productivity and contributes to economic growth (Del Bo, 2016). Innovation also contributes to economic 

capability

growth (Boons et al., 2013), for the market demands innovative products (Weissbrod; Bockem, 2017).

Innovation activities lead companies to join new markets and improve their competitiveness (Manual do OECD, 2005; Ramos; Zilber, 2015). Innovation shows the economic development revitalization (Coad; Segarra; Teruel, 2016), which is responsible for the increase of industrial efficacy, and promotes the companies' competitiveness and organizational performance. It is important to identify the main characteristics and factors that promote innovation activities in order to understand the process of innovation, and to design public policies that can support and encourage companies to invest in innovation (Manual do OECD, 2005).

The EU Industrial R\&D Investment Scoreboard, which is organized by the European Commission's Joint Research Centre, is an evaluation board published yearly and which collects data from companies worldwide by providing economic-financial data from the biggest $R \& D$ investors, with the objective to support the formulators of policies and encourage companies to disclose information about their investments in R\&D. The 2018 issue encompassed the 2,500 companies that invested the most in R\&D in the years 2017 and 2018.

The 2018 Global Competitiveness Report (GCR) presents information on the data collected by the World Economic Forum. This report presents the Global Competitiveness Index (GCI), which assesses the critical factors for competitiveness in the Fourth Industrial Revolution (4IR). According to GCR, every economy must invest in measures that improve their competitiveness in order to support growth and income in the future.

Innovation is one of the pillars that GCI assesses as a world competitiveness index. By comparing the two reports, this study aims at analyzing whether the companies which invest the most in $R \& D$ and the most profitable companies are located in countries with the highest levels of competitiveness and innovation capability. According to the 2018 GCR, innovation capability is composed of indexes, such as research and development (to develop inventions) and commercialization (the capability to bring innovation into the successful market). However, the economies which rank the highest in Innovation Capability show that their innovation ecosystems are more developed. As innovation was the weakest foundation in the 2018 GCR, it is possible to conclude that these countries show a limited innovation capability.

This study intends to contribute to the Administration area by relating innovation and competitiveness topics, and supplying information on the countries' competitiveness and R\&D investment in the companies. Through the analysis of the correlation between R\&D investment 
in the companies and the countries' competitiveness, this study's findings will help other studies that intend to identify if the so-called most competitive countries attract the shareholders' private interests, that is, shareholders to invest in their companies and which have high R\&D investments. This study is relevant, for it identifies the correlation between companies' performance and countries' performance, with the objective to understand whether the countries' competitiveness is related to the companies' performance or vice-versa. It also intends to check whether the most profitable companies are located in the most competitive countries.

Besides this introductory section, this article is composed of a section that presents the theoretical framework and the hypotheses mapping. Then, the section on methodology showing the statistic tests used in order to reach the objectives, followed by the section that contains the results' presentation and analysis. In the end, it presents the final remarks and the bibliographic references.

\section{Background}

\subsection{Competitiveness}

The competitiveness of a country comes from its position in the international market and it refers to the environment that provides a higher value creation to its companies (Garelli, 2003) and that meets its business needs (Haj Youssef; Hussein; Christodoulou, 2019). To the World Economic Forum, competitiveness is the set of institutions, policies and factors that determine the country's productivity level (GCR, 2018). To Kisel'áková et al. (2018), world competitiveness is the country's capacity to manage its resources and opportunities that are available to increase its inhabitants' prosperity. Competitiveness is one of the main indexes to assess the economies' performance (Kisel'áková et al., 2018; Korauš; Mazák; Dobrovič, 2018). The countries that are at the top of the rank give more emphasis to saving knowledge, research, innovation, technology and IT sector, which are key factors for competitiveness and sustainable growth (Kisel'áková et al., 2018).

The Global Competitiveness Report (GCR) aims at securing the micro- and macroeconomic foundations of national competitiveness (Rosenbaum, 2011). GCR helps with the discussions on issues pertaining to international competitiveness (Kisel'áková et al., 2018) and is designed with the objective to help political decision makers and entrepreneurial leaders to 

capability

shape their economic strategies in the Fourth Industrial Revolution age (GCR, 2018). GCI is used in academic studies to observe competitiveness dynamics (Kalim; Arshed; Shaheen, 2019). An example of a study that used GCI indexes was the one by Amorós, Poblete and Mandakovic (2019), which aimed at understanding whether some resources significantly influence the entrepreneurs' probability to have high growth expectancies in innovative entrepreneurships by using Global Entrepreneurship Monitor and GCI data. However, GCI used two indexes: business sophistication and the pillar of innovation. The authors found out that environments that are guided into innovation increase the number of ambitious and innovative entrepreneurs. There is also the study by Kiseláková et al. (2018), which used the GCI index results to identify the impact of the main factors that affect the countries' competitive positions, and the research by Crescente-Romero, Giménez-Balzado \& del Val-Núñez (2019), who analyzed the countries' level of competitiveness during the countries' economic recovery phase by using Global Entrepreneurship Monitor and GCI data. The 4.0 Global Competitiveness Index (GCI) is organized into 12 pillars and four competitiveness factors. The pillars are: 1 . Institutions; 2. Infrastructure; 3. The adoption of information and communication technologies; 4. Macro-economic stability; 5. Health; 6. Education and skills; 7. Product market; 8. Job market; 9. Financial system; 10. Market size; 11. Entrepreneurial dynamism; and 12. Innovation capability. The four factors are: institutional environment, human capital, markets and innovation ecosystem. Each pillar and factor is assessed through a scale that ranges from 0 to 100. According to a study by Farinha et al. (2018), the pillars which best explain global competitiveness are: 1 - Institutions; 2 - Infrastructure; 5 - Higher education and training; 7 Job market development; 8 - Financial market development; 9 - Technological readiness; 11 Business sophistication; and 12 - Innovation. This research will only analyze the pillar concerning innovation.

The suggested study will use the pillar of competitiveness and the countries' innovation capability, since they are the pillars that address the factors of interest in this study. Investments in research and development (R\&D) are important for competitiveness gains (ROCHA et al., 2015). According to studies by Rocha et al. (2015), innovations will only succeed in the companies depending on their investments in R\&D. The results of a study by Abrantes, Pereira and Botelho (2020) concluded that the incentives represent positive effects in the competitiveness of small and medium enterprises (SMEs) after the third year of investment in $R \& D$, that is, the returns over investments in $R \& D$ in SMEs are not immediate. 
On the importance of innovation to improve the competitiveness position of the national economy in the world, the authors Novikov et al. (2019) identified, in their study, that Russia developed a positive trend in R\&D financing up to the year 2030, and identified it will improve their position in the global competitiveness index.

As explained previously, it is possible to state that the companies which invested in R\&D improved their country's competitiveness. Therefore, the companies which invest the most in R\&D in the world are located in the countries with the highest competitiveness level. Moreover, it is possible to understand that the countries that have high innovation capabilities also have the companies that invest heavily in R\&D. Based on this assumption, here is the following hypothesis:

H1: Companies with a higher percentage of $R \& D$ rate are located in countries with the highest competitiveness score.

Some studies analyzed the impact of companies' profitability over the countries' competitiveness. According to Francis (1992), the way the companies contribute to the performance of a country is based on their strategic planning. Since the increase of a company's profitability is always present in their strategic planning, countries with companies that encourage the search for their own growth are more competitive (Haj Youssef; Hussein; Christodoulou, 2019). The research by Grau and Reig (2020) stated that the profitability of a key sector in the European economy directly affects the competitiveness of a sector. Thus, another assumption comes from the principle that the companies in countries with the highest levels of competitiveness are those with the highest percentage of profitability.

$\mathrm{H} 2$ : The companies with the highest percentage of profitability are located in countries with the highest score of competitiveness.

\subsection{Innovation Capability}

Companies' innovation improves with innovation activities (Coad; Rao, 2006; Cheng; Huizingh, 2014). Innovation generates competitive advantages in several ways for the companies, whether by keeping new market shares or by increasing their profitability (Tidd, 

capability

Bessant \& Pavitt, 2008). Companies that innovate invest in research and development (R\&D) and obtain competitive gains (Rocha et al., 2015), but innovative companies are more prepared to face competition, and present higher growth rates than those that are not innovative (Spescha; Woerter, 2019).

The budget of investment in $\mathrm{R} \& \mathrm{D}$ of a company varies according to its technologic strategy and the activity sector where it operates. The increase of activities concerning R\&D in high technology industries is configured as a barrier against the introduction of new competitors, which enables high R\&D returns, whereas $R \& D$ returns are lower in low technology companies because they are innovations that are easier to copy (Spescha; Woerter, 2019). In companies, the R\&D investment efforts can be measured through the percentage of investments concerning the revenue (Tigre, 2006). Job growth (Coad; Grassano, 2019) and sales growth (Coad; Grassano, 2019; Spescha; Woerter, 2019) are also stimuli for R\&D investments but, according to Coad and Grassano (2019), the financial performance has little influence over R\&D investment.

On a macro level, the companies' innovation potential increase boosts the domestic wealth in a country (Spescha; Woerter, 2019). Without innovation in the companies, national economy steadies and presents no changes (Spescha; Woerter, 2019). For such, innovation is important for the development and growth of the countries (Buesa et al., 2010; Feldman et al. 2019), which reinforces the importance of policies that strengthen $R \& D$ activities in companies (Buesa et al., 2010; Coad; Grassano, 2019).

According to Karadayi and Ekinci (2019), studies on R\&D efficiency can be divided into two groups: one that assesses the companies' efficiency, and one that deals with the countries' efficiency. The second group provides important information for policy makers in countries concerning $R \& D$ activities. These formulators must design policies that increase R\&D investments in order to attract foreign resources (Tsamadias et al., 2019). It is understood that the countries which present a high $R \& D$ performance have political stability and a high quality regulatory environment (Karadayi; Ekinci, 2019). The policy makers who are the formulators of public policies must provide flexible institutional environments in order to reach a higher national performance (Haj Youssef; Hussein; Christodoulou, 2019). The study by Haj Youssef, Hussein and Christodoulou (2019) concluded that the countries that offer the strongest action support to their companies' executives are more competitive. The State is responsible for the creation of healthy competitive environments through the creation of a legislative environment that is favorable to the flow of capitals, goods, services, human capital, financial 
capital, and to the removal of barriers and the creation of opportunities (Korauš; Mazák; Dobrovič, 2018).

Investing in R\&D improves companies' innovation and the nations' competitiveness, besides leading the country into economic growth (Karadayi; Ekinci, 2019). The study by Farinha, Ferreira and Nunes (2018) showed a strong correlation between the countries' competitiveness and innovation. This study confirmed that one of the most relevant innovation items was the company's expenses with R\&D. Boosting a country's competitiveness depends on their company's skills to innovate (Haj Youssef; Hussein; Christodoulou, 2019).

$R \& D$ investment has a positive impact on the growth of developing countries (Andreassi e Sbragia, 2002). Such growth comes from the companies' process of innovation along with what is already happening in developed countries: most R\&D activities are done in companies in these countries. A country's innovation policies are major boosters in the companies to conduct R\&D investments (Fernández-Sastre; Montalvo-Quizhpi, 2019), which leads to the assumption that the companies which invest the most in R\&D are located in the most innovative countries.

H3: The companies with the highest percentage of R\&D intensity are located in countries with the highest score of innovation capability.

Innovation can generate a competitive advantage in several ways to companies. New products keep new market shares and increase the markets' profitability (Tidd, Bessant \& Pavitt, 2008). In other words, investing in R\&D brings more innovative companies that will have an increase in their productivity and which will contribute to their economic growth (Del Bo, 2016). This leads to the assumption that the companies which will have the largest profits will be located in the most innovative countries.

H4: The companies with the highest profitability percentage are located in countries with the highest innovation capability score.

\section{Method}

In order to analyze the correlation between the companies' investments in research and development (R\&D) and the countries' competitiveness, a descriptive research with a quantitative approach was carried out. In a quantitative research, with the use of numerical measure and statistical analysis, the data are analyzed to test the hypotheses raised in the research (Perovano, 2016). 

capability

The data used in this study were extracted from two analysis resources. The first one was the 2018 EU Industrial R\&D Investment Scoreboard issue. The population of this study basis was composed of 2,500 companies. This research chose to use the first 500 companies and tried to analyze, in a universe of 2,500 companies, those which invest the most in $R \& D$, which is the aim of this research. The sample calculation recommended a sample of 334 companies, with an error margin of 5\% and a reliability level of 95\% (Hair Jr. et al., 2005). The other resource was the 2018 Global Competitiveness Report, which studied the data from 140 economies. Only the data from the countries that host the 500 companies used in this study were used. Seven companies were ruled out because they didn't present all the data (profitability percentage in the report), totaling 493 companies analyzed.

From the EU Industrial R\&D Investment Scoreboard report, data related to the percentage of R\&D investment intensity were extracted, along with the percentage of companies' profitability. From GCR, the competitiveness scores were extracted (which is defined as a set of institutions, policies and factors that determine the level of productivity) and the countries' innovation capability (defined as R\&D quality and quantity, a measure that the country's environment uses to encourage the collaboration, creativity and the capacity to transform ideas into new goods and services). The competitiveness scores measure the national competitiveness, which is defined as a set of institutions, policies and factors that determine the level of productivity. Innovation capability is composed of less tangible indexes from idea generation, such as research and development (to develop inventions) and commercialization (the capability to introduce innovation into the market). Table 1 presents the hypotheses and the variables' operationalization.

Table 1

Variables' hypotheses and operationalization.

\begin{tabular}{l|l|ll}
\hline \multicolumn{1}{c}{ Hypothesis } & \multicolumn{1}{|c}{ Variables } & \multicolumn{2}{|c}{ Variable's Operationalization } \\
\hline H1: Companies with a higher & R\&D intensity percentage. & $\begin{array}{l}2018 \text { EU Industrial R\&D Investment } \\
\text { Scoreboard report. }\end{array}$ \\
percentage of R\&D rate are & & 2018 GCR competitiveness score. \\
\cline { 2 - 4 } $\begin{array}{l}\text { located in countries with the } \\
\text { highest competitiveness score. }\end{array}$ & Competitiveness score. & 2018 EU Industrial R\&D Investment \\
\hline H2: The companies with the & Profitability percentage. & Scoreboard report. & \\
highest percentage of profitability & & 2018 GCR competitiveness score. \\
\cline { 2 - 4 } $\begin{array}{l}\text { are located in countries with the } \\
\text { highest score of competitiveness. }\end{array}$ & Competitiveness score. & & \\
\end{tabular}




\begin{tabular}{|c|c|c|}
\hline \multirow{2}{*}{$\begin{array}{l}\text { H3: The companies with the } \\
\text { highest percentage of R\&D } \\
\text { intensity are located in countries } \\
\text { with the highest score of } \\
\text { innovation capability. }\end{array}$} & R\&D intensity percentage. & $\begin{array}{l}2018 \text { EU Industrial R\&D Investment } \\
\text { Scoreboard report. }\end{array}$ \\
\hline & $\begin{array}{l}\text { Innovation } \\
\text { score. }\end{array}$ & 2018 GCR competitiveness score. \\
\hline \multirow{2}{*}{$\begin{array}{l}\text { H4: The companies with the } \\
\text { highest profitability percentage } \\
\text { are located in countries with the } \\
\text { highest innovation capability } \\
\text { score. }\end{array}$} & Profitability percentage. & $\begin{array}{l}2018 \text { EU Industrial R\&D } \text { Investment } \\
\text { Scoreboard report. }\end{array}$ \\
\hline & $\begin{array}{l}\text { Innovation } \\
\text { score. }\end{array}$ & 2018 GCR competitiveness score. \\
\hline
\end{tabular}

Source: Elaborated by author

These data were prepared onto an Excel spreadsheet in order to be exported, and analyzed by an inferential statistic through the SPSS Statistics (V.24) software. In order to operationalize the analysis in relation to the competitiveness score and the innovation capability, a cluster analysis for group formation was performed.

In order to organize the factors and variables, two preliminary steps were taken for the competitiveness score and the innovation capability score: i) the application of the dendrogram analysis, and 2) the Cluster K-means grouping algorithm, with the objective to extract characteristics that are hidden from the data, and develop the hypothesis concerning its nature (Linden, 2009). The result of this analysis produced three company clusters, distributed according to Table 2 for the competitiveness score. Table 3 shows the companies' cluster for the innovation capability score.

Table 2

Number of cases in each cluster for the competitiveness score.

\begin{tabular}{c|c|c}
\hline Number of clusters & Mean score & Number of cases \\
\hline 1 & 60.9 & 7 \\
\hline 2 & 73.5 & 362 \\
\hline 3 & 83.6 & 124 \\
\hline
\end{tabular}

Source: Elaborated by author

Table 3 

capability

Number of cases in each cluster for the innovation capability score.

\begin{tabular}{c|c|c}
\hline Number of clusters & Mean score & Number of cases \\
\hline 1 & 48.5 & 24 \\
\hline 2 & 68.8 & 125 \\
\hline 3 & 83.5 & 344 \\
\hline
\end{tabular}

Source: Elaborated by author

The correlations between the variables were analyzed with the use of: i) two-way ANOVA to check the influence of two different categorical independent variables; ii) the Tukey's post-hoc test, to identify the location of the significant differentials involving the estimates of the safety interval of the differences between the several cluster means, according to Maroco (2011). The lowest significant difference was defined by the Tukey's test strategy, and statistically considers as significant the effects whose value is $p$-value $\leq 0.05$.

\section{Results and Discussion}

The 2018 EU Industrial R\&D Investment Scoreboard issue listed the 2,500 companies that invested the most in R\&D in the world in 2017 and 2018. These companies are located in 46 countries, 577 of them (23.08\%) in the European Union, 778 (31.12\%) are American, 339 $(13.56 \%)$ are Japanese, $438(17.52 \%)$ are Chinese, and $368(14.72 \%)$ are located in other parts of the world. The indexes that were used from the 2018 EU Industrial R\&D Investment Scoreboard issue were: percentage of R\&D intensity, which represents how much of their sales were invested in $R \& D$; and the company's profitability percentage during the time analyzed. The first ten companies in the world ranking are shown in Table 4.

\section{Table 4}

The top 10 companies in the 2018 EU Industrial R\&D Investment Scoreboard. 


\begin{tabular}{c|c|c|c|c|c|c}
\multicolumn{2}{c}{} & \multicolumn{2}{r|}{$\begin{array}{r}\text { 2018 EU Industrial R\&D } \\
\text { Investment Scoreboard }\end{array}$} & \multicolumn{2}{|c}{$\begin{array}{c}\text { 2018 Global } \\
\text { Competitiveness Report }\end{array}$} \\
\hline $\begin{array}{c}\text { World } \\
\text { Ranking }\end{array}$ & Company & Country & $\begin{array}{c}(\%) \text { R\&D } \\
\text { intensity }\end{array}$ & $\begin{array}{c}(\%) \\
\text { Profitability }\end{array}$ & Score & $\begin{array}{c}\text { Innovation } \\
\text { Capability }\end{array}$ \\
\hline 1 & SAMSUNG & South Korea & 7.2 & 22.4 & 67.5 & 47.4 \\
\hline 2 & ALPHABET & US & 14.5 & 26.1 & 85.6 & 86.5 \\
\hline 3 & VOLKSWAGEN & Germany & 5.7 & 5.8 & 82.8 & 87.5 \\
\hline 4 & MICROSOFT & US & 13.3 & 31.7 & 85.6 & 86.5 \\
\hline 6 & INTEL & US & 20.9 & 27.8 & 85.6 & 86.5 \\
\hline 7 & APPLE & US & 5.1 & 26.8 & 85.6 & 86.5 \\
\hline 8 & ROCHE & Switzerland & 19.5 & 23.2 & 82.6 & 82.1 \\
\hline 10 & JOHNSON \& & US & 13.8 & 24.8 & 85.6 & 86.5 \\
\hline JOHNSON & DAIMLER & Germany & 5.3 & 8.9 & 82.8 & 87.5 \\
\hline
\end{tabular}

Source: Elaborated by author

Out of the companies that invest the highest percentage in $R \& D$, eight are American companies, one is Chinese and one is British. From the ten companies that presented the highest profitability in the time researched, four are American, three are Australian, one is Danish, one is South Korean and one is Italian. In 2017/2018, € 736.4 billion were invested in R\&D. However, industrial R\&D is very concentrated around a few companies and sectors. According to the 2018 EU Industrial R\&D Investment Scoreboard issue, when it comes to profitability, the companies presented a stable behavior but a meaningful increase in the last two years.

Concerning competitiveness, and according to the 2018 Global Competitiveness Report, the top ten countries in competitiveness are: the United States, Singapore, Germany, Switzerland, Japan, Holland, the United Kingdom, Sweden, Denmark and Finland; and the top ten countries in innovation capability are: Germany, the United States, Switzerland, Thailand, Sweden, Japan, the United Kingdom, South Korea, Holland and Finland. Upon comparing the two groups, it is possible to see that Singapore and Denmark appear as the top ten countries in competitiveness but not in innovation capability (their innovation capability scores are 75 and 75.4, respectively). Likewise, Taiwan and South Korea appear in the innovation capability list but not in the competitiveness list (their competitiveness scores are 79.3 and 78.8, respectively). The remaining countries appear in both lists. 

capability

In order to test the study hypotheses, ANOVA was used to assess the significance of the correlations presented in these hypotheses. H1 hypothesis aimed at identifying whether the companies with the highest $\mathrm{R} \& \mathrm{D}$ percentage are located in countries with the highest competitiveness scores. The ANOVA correlation between the company's R\&D intensity percentage and the country's competitiveness score is not statistically significant (p-value > $0.05)$, according to Table 5.

Table 5

ANOVA correlation between the company's R\&D intensity percentage and the country's competitiveness score.

\begin{tabular}{|c|c|c|c|c|c|c|}
\hline & & $\begin{array}{l}\text { Sum of } \\
\text { Squares }\end{array}$ & $\mathrm{gl}$ & $\begin{array}{c}\text { Mean } \\
\text { Square }\end{array}$ & $\mathrm{F}$ & Sig. \\
\hline \multirow[t]{3}{*}{ R\&D intensity (\%) } & $\begin{array}{c}\text { Between } \\
\text { Groups }\end{array}$ & 4769.990 & 2 & 2384.995 & 1.285 & .278 \\
\hline & $\begin{array}{l}\text { In the } \\
\text { groups }\end{array}$ & 909299.964 & 490 & 1855.714 & & \\
\hline & Total & 914069.955 & 492 & & & \\
\hline
\end{tabular}

Source: Elaborated by author

The Tukey's post-hoc test didn't find any significant differentials (p-value > 0.05) in the location of the significant differentials involving the estimates of the safety interval of the differences between the several cluster means concerning hypothesis 1 (see Table 6).

It can be stated that there is no difference between the groups and there is no correlation between $R \& D$ investment in the companies and the country's competitiveness. In other words, the companies which invest the most in R\&D are not necessarily located in countries that have a high competitiveness score. According to Karadayi and Ekinci (2019), the studies on R\&D investment efficiency are grouped up in two: one measures the companies' efficiency, the other one measures the country's efficiency. Studies by Karadayi and Ekinci (2019) and by Wang and Huang (2007) stated that R\&D investment improves the nations' competitiveness. What this study showed is that $\mathrm{R} \& \mathrm{D}$ activities in companies do not necessarily guarantee the competitiveness of the country where the company is located, which confirms the studies by Karadayi and Ekinci (2019) and by Wang and Huang (2007).

\section{Table 6}


Tukey's post-hoc test of the correlation between R\&D intensity in the company and the country's competitiveness score.

\begin{tabular}{|c|c|c|c|c|c|c|c|}
\hline \multirow[b]{2}{*}{$\begin{array}{l}\text { Dependent } \\
\text { variable }\end{array}$} & \multirow[b]{2}{*}{$\begin{array}{l}\text { (I) Cluster } \\
\text { case number }\end{array}$} & \multirow{2}{*}{$\begin{array}{c}\text { (J) Cluster } \\
\text { case } \\
\text { number }\end{array}$} & \multirow{2}{*}{$\begin{array}{c}\text { Mean } \\
\text { difference } \\
\text { (I-J) }\end{array}$} & \multirow[b]{2}{*}{$\begin{array}{c}\text { Standard } \\
\text { Error }\end{array}$} & \multirow[b]{2}{*}{ Sig. } & \multicolumn{2}{|c|}{$\begin{array}{l}\text { 95\% Confidence } \\
\text { Interval }\end{array}$} \\
\hline & & & & & & $\begin{array}{l}\text { Lower } \\
\text { limit }\end{array}$ & $\begin{array}{l}\text { Upper } \\
\text { limit }\end{array}$ \\
\hline \multirow{6}{*}{$\begin{array}{l}\text { R\&D intensity } \\
(\%)\end{array}$} & \multirow[t]{2}{*}{1} & 2 & -1.09655 & 16.73522 & .998 & -40.4386 & 38.2455 \\
\hline & & 3 & -8.07401 & 16.43862 & .876 & -46.7188 & 30.5708 \\
\hline & \multirow[t]{2}{*}{2} & 1 & 1.09655 & 16.73522 & .998 & -38.2455 & 40.4386 \\
\hline & & 3 & -6.97746 & 4.48238 & .266 & -17.5149 & 3.5600 \\
\hline & \multirow[t]{2}{*}{3} & 1 & 8.07401 & 16.43862 & .876 & -30.5708 & 46.7188 \\
\hline & & 2 & 6.97746 & 4.48238 & .266 & -3.5600 & 17.5149 \\
\hline
\end{tabular}

Source: Elaborated by author

Hypothesis $\mathrm{H} 2$ tried to understand whether the companies which have the highest profitability are located in countries with the highest competitiveness score. The ANOVA test presented no statistical significance ( $\mathrm{p}$-value $>0.05$ ), according to Table 7 , which shows that the companies' profitability means are different from the country's competitiveness score means.

Table 7

ANOVA correlation between the company's profitability percentage and the country's competitiveness score.

\begin{tabular}{l|c|c|c|c|c|c}
\hline & & $\begin{array}{c}\text { Sum of } \\
\text { Squares }\end{array}$ & gl & $\begin{array}{c}\text { Mean } \\
\text { Square }\end{array}$ & F & Sig. \\
\hline Profitability (\%) & $\begin{array}{c}\text { Between } \\
\text { Groups }\end{array}$ & 262.700 & 2 & 131.350 & .094 & .910 \\
\cline { 2 - 7 } & $\begin{array}{c}\text { In the } \\
\text { groups }\end{array}$ & 684467.368 & 490 & 1396.872 & & \\
\cline { 2 - 7 } & Total & 684730.068 & 492 & & & \\
\hline
\end{tabular}

Source: Elaborated by author

In both the H1 and H2 hypotheses, the Tukey's post-hoc test didn't find any significant differentials in the location of the significant differentials involving the estimates of the safety interval of the differences between the several cluster means ( $p$-value >0.05) (see Table 8). 

capability

As in the correlation between companies' R\&D investment intensity and the country's competitiveness, the correlation between the companies' profitability and the country's competitiveness is not a direct correlation, that is, the companies which have higher profitability are not located in countries with the highest competitiveness scores. Innovation activities increase the companies' profitability (Tidd, Bessant \& Pavitt, 2008) and bring competitiveness gains for the companies (Rocha et al., 2015), but not from the country where it is located. According to the conclusions from studies by Andreassi and Sbragia (2002), the R\&D investments that come from companies' innovation positively impact the country's growth. Moreover, the study by Spescha \& Woerter (2019) stated that the company's innovation potential growth increases the country's wealth, since the correlation between companies' profitability and country's competitiveness presented no significance in this study, which confirms articles previously mentioned. This will take a more detailed study to understand why the companies which invest the most in $R \& D$ in the world are not located in the most competitive countries, and also to understand whether the policies in competitive countries are strengthening R\&D activities in companies, as suggested by Buesa et al. (2010).

\section{Table 8}

Tukey's post-hoc test of the correlation between the company's profitability percentage and the country's competitiveness score.

\begin{tabular}{|c|c|c|c|c|c|c|c|}
\hline \multirow[b]{2}{*}{$\begin{array}{c}\text { Dependent } \\
\text { variable }\end{array}$} & \multirow{2}{*}{$\begin{array}{l}\text { (I) Cluster } \\
\text { case } \\
\text { number }\end{array}$} & \multirow[b]{2}{*}{$\begin{array}{l}\text { (J) Cluster } \\
\text { case number }\end{array}$} & \multirow{2}{*}{$\begin{array}{c}\text { Mean } \\
\text { difference } \\
(\mathrm{I}-\mathrm{J})\end{array}$} & \multirow[b]{2}{*}{$\begin{array}{c}\text { Standard } \\
\text { Error }\end{array}$} & \multirow[b]{2}{*}{ Sig. } & \multicolumn{2}{|c|}{$\begin{array}{c}95 \% \text { Confidence } \\
\text { Interval }\end{array}$} \\
\hline & & & & & & $\begin{array}{l}\text { Lower } \\
\text { limit }\end{array}$ & $\begin{array}{c}\text { Lower } \\
\text { limit }\end{array}$ \\
\hline \multirow[t]{6}{*}{ Profitability (\%) } & \multirow[t]{2}{*}{1} & 2 & 5.74747 & 14.51958 & .917 & -28.3860 & 39.8809 \\
\hline & & 3 & 6.11532 & 14.26226 & .904 & -27.4132 & 39.6438 \\
\hline & \multirow[t]{2}{*}{2} & 1 & -5.74747 & 14.51958 & .917 & -39.8809 & 28.3860 \\
\hline & & 3 & .36784 & 3.88894 & .995 & -8.7745 & 9.5102 \\
\hline & \multirow[t]{2}{*}{3} & 1 & -6.11532 & 14.26226 & .904 & -39.6438 & 27.4132 \\
\hline & & 2 & -.36784 & 3.88894 & .995 & -9.5102 & 8.7745 \\
\hline
\end{tabular}

Source: Elaborated by author 
According to the ANOVA correlation between the company's R\&D intensity percentage and the country's innovation capability score, H3 hypothesis confirmed that this correlation has no statistical significance $(\mathrm{p}$-value $=0.202)$, according to Table 9 .

\section{Table 9}

ANOVA correlation between the company's R\&D intensity percentage and the country's innovation capability score.

\begin{tabular}{l|c|c|c|c|c|c}
\hline & & $\begin{array}{c}\text { Sum of } \\
\text { Squares }\end{array}$ & gl & Square & F & Sig. \\
\hline R\&D intensity (\%) & $\begin{array}{c}\text { Between } \\
\text { Groups }\end{array}$ & 5948.226 & 2 & 2974.113 & 1.605 & .202 \\
\cline { 2 - 7 } & $\begin{array}{c}\text { In the } \\
\text { groups }\end{array}$ & 908121.729 & 490 & 1853.310 & & \\
\hline
\end{tabular}

Source: Elaborated by author

For the H3 hypothesis correlation, the Tukey's post-hoc test, once again, found no significant differentials ( $\mathrm{p}$-value $>0.05$ ) in the location of the significant differentials involving the estimates of the safety interval of the differences between the several cluster means (see Table 10).

It can't be stated that the companies which have a higher percentage of R\&D intensity are located in countries with the highest innovation capability scores. To Andreassi and Sbragia (2002), investing in R\&D increases the country's development, but the process of companies' innovation is influenced by $R \& D$ investments. However, according to this research data, high R\&D indexes in the companies improve their innovation but not the innovation capability of the countries where they are located. According to the 2018 GCR, innovations increase the economic productivity only if they reach the desired markets and their commercial success. Innovation takes place inside an ecosystem of multiple factors, as stated by the 2018 GCR. Any factor the innovation ecosystem misses may stop new ideas from being generated or commercialized. Moreover, the index that was designed may catch this complexity and assess the countries in relation to such complexity. 
Table 10

Tukey's post-hoc test of the correlation between the company's R\&D intensity percentage and the country's innovation capability.

\begin{tabular}{|c|c|c|c|c|c|c|c|}
\hline \multirow[b]{2}{*}{$\begin{array}{c}\text { Dependent } \\
\text { variable }\end{array}$} & \multirow{2}{*}{$\begin{array}{l}\text { (I) Cluster } \\
\text { case } \\
\text { number }\end{array}$} & \multirow{2}{*}{$\begin{array}{c}\text { (J) Cluster } \\
\text { case } \\
\text { number }\end{array}$} & \multirow{2}{*}{$\begin{array}{c}\text { Mean } \\
\text { difference } \\
(\mathrm{I}-\mathrm{J})\end{array}$} & \multirow[b]{2}{*}{$\begin{array}{c}\text { Standard } \\
\text { Error }\end{array}$} & \multirow[b]{2}{*}{ Sig. } & \multicolumn{2}{|c|}{$\begin{array}{c}\text { 95\% Confidence } \\
\text { Interval }\end{array}$} \\
\hline & & & & & & $\begin{array}{l}\text { Lower } \\
\text { limit }\end{array}$ & $\begin{array}{c}\text { Lower } \\
\text { limit }\end{array}$ \\
\hline \multirow[t]{6}{*}{ R\&D intensity (\%) } & \multirow[t]{2}{*}{1} & 2 & -3.34817 & 9.59415 & .935 & -25.9026 & 19.2063 \\
\hline & & 3 & -10.22785 & 9.08894 & .499 & -31.5946 & 11.1389 \\
\hline & \multirow[t]{2}{*}{2} & 1 & 3.34817 & 9.59415 & .935 & -19.2063 & 25.9026 \\
\hline & & 3 & -6.87968 & 4.49600 & .278 & -17.4491 & 3.6898 \\
\hline & \multirow[t]{2}{*}{3} & 1 & 10.22785 & 9.08894 & .499 & -11.1389 & 31.5946 \\
\hline & & 2 & 6.87968 & 4.49600 & .278 & -3.6898 & 17.4491 \\
\hline
\end{tabular}

Source: Elaborated by author

Finally, the H4 hypothesis, which aimed at analyzing the companies' profitability percentage correlation with the country's innovation capability, obtained the same results from the other hypotheses. Moreover, it presented no statistical significance $(p$-value $=0.602)$ in the correlation when ANOVA was applied (see Table 11).

Table 11

ANOVA correlation between the company's profitability percentage and the country's innovation capability score.

\begin{tabular}{l|c|c|c|c|c|c}
\hline & & $\begin{array}{c}\text { Sum of } \\
\text { Squares }\end{array}$ & gl & Square & F & Sig. \\
\hline Profitability (\%) & $\begin{array}{c}\text { Between } \\
\text { Groups }\end{array}$ & 1417.707 & 2 & 708.854 & .508 & .602 \\
\cline { 2 - 7 } & $\begin{array}{c}\text { In the } \\
\text { groups }\end{array}$ & 683312.361 & 490 & 1394.515 & & \\
\cline { 2 - 7 } & Total & 684730.068 & 492 & & & \\
\hline
\end{tabular}

Source: Elaborated by author 
According to the remaining hypotheses, the Tukey's post-hoc test of the H4 hypothesis found no significant differentials in the location of the significant differentials involving the estimates of the safety interval of the differences between the several cluster means (see Table 12).

Besides, it can't be stated that the companies which had the highest profitability are located in countries with the highest innovation capability scores. By analyzing the table with the companies' profitability values and the competitiveness score of the country where they are located, it is possible to see that two out of the first five most competitive companies are located in Australia, which doesn't have a high innovation capability score (69.9). The company's innovation potential increases the country's wealth (Spescha; Woerter, 2019). However, according to this research data, the opposite was not confirmed, which suggests the need to better understand the findings of this study and bear in mind that profitable companies can help the country's innovation capability.

\section{Table 12}

Tukey's post-hoc test of the correlation between the company's profitability and the country's innovation capability score.

\begin{tabular}{|c|c|c|c|c|c|c|c|}
\hline \multirow[b]{2}{*}{$\begin{array}{c}\text { Dependent } \\
\text { variable }\end{array}$} & \multirow[b]{2}{*}{$\begin{array}{l}\text { (I) Cluster } \\
\text { case number }\end{array}$} & \multirow{2}{*}{$\begin{array}{c}\text { (J) Cluster } \\
\text { case } \\
\text { number }\end{array}$} & \multirow{2}{*}{$\begin{array}{c}\text { Mean } \\
\text { difference } \\
(\mathrm{I}-\mathrm{J})\end{array}$} & \multirow[b]{2}{*}{$\begin{array}{c}\text { Standard } \\
\text { Error }\end{array}$} & \multirow[b]{2}{*}{ Sig. } & \multicolumn{2}{|c|}{$95 \%$ Confidence Interval } \\
\hline & & & & & & Lower limit & $\begin{array}{l}\text { Lower } \\
\text { limit }\end{array}$ \\
\hline \multirow[t]{6}{*}{ Profitability (\%) } & \multirow[t]{2}{*}{1} & 2 & 1.13292 & 8.32231 & .990 & -18.4316 & 20.6975 \\
\hline & & 3 & 4.60933 & 7.88407 & .828 & -13.9250 & 23.1436 \\
\hline & \multirow[t]{2}{*}{2} & 1 & -1.13292 & 8.32231 & .990 & -20.6975 & 18.4316 \\
\hline & & 3 & 3.47641 & 3.89999 & .646 & -5.6919 & 12.6447 \\
\hline & \multirow[t]{2}{*}{3} & 1 & -4.60933 & 7.88407 & .828 & -23.1436 & 13.9250 \\
\hline & & 2 & -3.47641 & 3.89999 & .646 & -12.6447 & 5.6919 \\
\hline
\end{tabular}

Source: Elaborated by author

By applying ANOVA to the correlation between the countries' competitiveness score and the countries' innovation capability score, even if this is not a hypothesis raised by this study, it is possible to see a statistical significance, where p-value co.05 (see Table 13), which shows that the countries with the highest competitiveness scores are those which presented the 

capability

highest innovation capability scores. In case this correlation didn't present any statistical significance, this would result in differences in the correlations upon analyzing the country's competitiveness and the country's innovation capability, along with the variables concerning $R \& D$ intensity percentage and profitability percentage.

\section{Table 13}

ANOVA correlation between the countries' competitiveness score and the countries' innovation capability sore.

\begin{tabular}{l|c|c|c|c|c}
\hline & Sum of Squares & $\mathrm{gl}$ & Mean Square & $\mathrm{F}$ & Sig. \\
\hline Between Groups & 128.518 & 2 & 64.259 & 990.953 & .000 \\
\hline In the groups & 31.774 & 490 & .065 & & \\
\hline Total & 160.292 & 492 & & & \\
\hline
\end{tabular}

Source: Elaborated by author

This confirms the findings by Farinha et al. (2018), who stated that innovation capability is one of the most important pillars to explain global competitiveness. There is also the study by Farinha, Ferreira and Nunes (2018), which showed a strong correlation between a country's competitiveness and innovation capability. This shows that the most competitive countries are those which have the highest innovation capability. The non-significance results in the correlations between R\&D intensity percentage and profitability percentage with the country's competitiveness and innovation capability presented similarities in their direct correlation between a country's competitiveness and innovation capability.

According to GCI (2018), the non-confirmation of the hypotheses raised in this study may be explained by the fact that most economies are striving to make innovation a meaningful mechanism of growth. Moreover, as pointed out by GCI (2018), innovation capability in many countries remains extremely limited, very concentrated or restricted to a few sectors, since the global mean score in the pillar concerning innovation was the lowest in relation to other pillars. However, it can be stated that what makes a country competitive is not the result of their companies' innovation, whether partly or on the whole, but the result of actions from other pillars that GCI analyzes, such as infrastructure, the adoption of information and communication technologies, economic stability, marketing, financial system and human capital.

According to GCI (2018), another notable difference was found in the sub-pillar of innovation concerning Research and Development, which had the lowest score. These 
statements by GCI (2018) may explain this research findings and the hypotheses' nonconfirmation.

\section{Conclusion}

The study aimed at analyzing whether the companies that invest the highest percentage in $R \& D$ and the most profitable companies are located in countries with the highest levels of competitiveness and innovation capability. The information on R\&D investments was extracted from the EU Industrial R\&D Investment Scoreboard (2018). For the countries' competitiveness index, the 2018 Global Competitiveness Report was used.

According to GCI (2018), competitive economies must prioritize deals that are swift and innovative. From such statement, this study tried to analyze whether there is a correlation between R\&D investments and companies' profitability with the countries' competitiveness and innovation capability. Four hypotheses were raised for this study and they analyzed the relationships of interest. After applying ANOVA in the correlations, the study identified that no correlations were statistically significant.

The first hypothesis, which tried to identify the correlation of the R\&D investment percentage variables and the countries' competitiveness score, confirmed a non-statistical significance. This correlation shows that the companies which invest the most in R\&D are not located in the most competitive countries. The second hypothesis analyzed the correlation of R\&D investment percentage variables and the country’s innovation capability score. Similar to the first hypothesis, this correlation was not statistically significant. That is, the companies which invest the most in $R \& D$ are not located in countries with the highest innovation capabilities.

The third hypothesis, which tried to correlate the companies' profitability percentage variables with the countries' competitiveness score, was not statistically confirmed. This shows that the companies with the highest profitability percentage are not located in countries that are considered more competitive. Then, the fourth hypothesis, which tried to correlate the companies' profitability percentage variables with the countries' innovation capability score followed the remaining hypotheses and was not statistically confirmed. Therefore, the companies with the highest profitability are not located in the countries with the highest innovation capability. 

capability

These findings confirm the statement by GCI (2018), that is, they can suggest that the most competitive economies may not prioritize swift and innovative deals. It can also be stated that the companies' innovation activities improve their competitiveness (Manual do OECD, 2005; Ramos; Zilber, 2015) but don't improve the competitiveness and the innovation capability of the country where they are located. According to a statement by Rocha et al. (2015), companies that innovate also invest in research and development (R\&D).

The study by Haj Youssef, Hussein and Christodoulou (2019) stated that boosting the competitiveness of a country may depend on their companies' ability to innovate. However, the authors found that the managerial description positively contributed to the national competitiveness, but they were not able to identify the mechanism through which the managerial description generates national competitiveness. So, they suggested this could be through innovation description. This research, however, was not able to confirm the authors' assumption, since it found that the most innovative companies are not necessarily located in the most competitive countries.

This research may contribute to studies which aim at analyzing the country's competitiveness and their correlations or antecedents. Moreover, this study aimed at identifying the relationship of the most innovative companies with the countries where they are located. These contributions are also suggestions for new researches on the topics concerning competitiveness and innovation.

The limitations presented in this study concern the statistical tool that was only applied to ANOVA, when the use of other statistical tools, such as regression or correlation analysis, could better analyze the correlations suggested and understand the importance of $R \& D$ investments and the countries' competitiveness profitability. However, according to this study's proposal, the statistical tests performed were found to meet this need.

\section{References}

Abrantes, L. M., Pereira, E. T., \& Botelho, A. (2020). The impact of R\&D incentives in the competitiveness of Portuguese SMEs. International Journal of Business Innovation and Research, 21(3), 336-355.

Amorós, J. E., Poblete, C., \& Mandakovic, V. (2019). R\&D transfer, policy and innovative ambitious entrepreneurship: evidence from Latin American countries. The Journal of Technology Transfer, 44(5), 1396-1415.

Buesa, M., Heijs, J. and Baumert, T. (2010), "The determinants of regional innovation in Europe: a combined factorial and regression knowledge production function approach", Research Policy, Vol. 39 No. 6, pp. 722-735, doi: 10.1016/j.respol.2010.02.016. 
Cheng, C. C., \& Huizingh, E. K. (2014). When is open innovation beneficial? The role of strategic orientation. Journal of product innovation management, 31(6), 1235-1253.

Coad, A., \& Rao, R. (2006). Innovation and market value: a quantile regression analysis. Economics Bulletin, 15(13).

Coad, A., \& Grassano, N. (2019). Firm growth and R\&D investment: SVAR evidence from the world's top R\&D investors. Industry and Innovation, 26(5), 508-533.

DOI: $10.1080 / 13662716.2018 .1459295$

Crecente-Romero, F., Giménez-Baldazo, M., \& del Val-Núñez, M. T. (2019). Competitiveness and entrepreneurship rate in Europe during the economic recovery phase, 20122016. International Entrepreneurship and Management Journal, 15(2), 455-470.

Farinha, L., Ferreira, J. J., \& Nunes, S. (2018). Linking innovation and entrepreneurship to economic growth. Competitiveness Review: An International Business Journal, 28(4), 451475. https://doi.org/10.1108/CR-07-2016-0045

Farinha, L., Nunes, S., Ferreira, J. J., \& Fernandes, A. (2018). Understanding the foundations of global competitive advantage of nations. Competitiveness Review: An International Business Journal, 28(5), 503-517. https://doi.org/10.1108/CR-10-2016-0063

Feldman, P. R., Jacomossi, R. R., Barrichello, A., \& Morano, R. S. (2019). The relationship between Innovation and Global Competitiveness: The mediating role of Management Practices evaluated by Structural Equation Modeling. Review of Business Management, 21(2), 195-212.

Fernández-Sastre, J., \& Montalvo-Quizhpi, F. (2019). The effect of developing countries' innovation policies on firms' decisions to invest in R\&D. Technological Forecasting and Social Change, 143, 214-223. https://doi.org/10.1016/j.techfore.2019.02.006

Francis, A. (1992), "The process of national industrial regeneration and competitiveness", Strategic Management Journal, Vol. 13 No. S2, pp. 61-78.

Garelli, S. (2003), "Competitiveness of nations: the fundamentals", IMD World Competitiveness Yearbook, Lausanne.

Global Competitive Report 2018. http://www3.weforum.org/docs/GCR2018/05FullReport/TheGlobalCompetitivenessReport 2018.pdf

Grau, A., \& Reig, A. (2020). Operating leverage and profitability of SMEs: agri-food industry in Europe. Small Business Economics, 1-22.

Haj Youssef, M. S., Hussein, H. M., \& Christodoulou, I. (2019). Competitiveness and managerial discretion: an empirical investigation at the national-level. Competitiveness Review: An International Business Journal, 29(2), 181-203. https://doi.org/10.1108/CR-012017-0011

Kalim, R., Arshed, N. and Shaheen, S. (2019), "Does competitiveness moderate inclusive growth: a panel study of low-income countries", Competitiveness Review, Vol. 29 No. 2, pp. 119-138. https://doi.org/10.1108/CR-11-2017-0074

Karadayi, M. A., \& Ekinci, Y. (2019). Evaluating R\&D performance of EU countries using categorical DEA. Technology Analysis \& Strategic Management, 31(2), 227-238.

Kiseláková, D., Šofranková, B., Čabinová, V., \& Onuferová, E. (2018). Competitiveness and sustainable growth analysis of the EU countries with the use of Global Indexes' methodology.

Korauš, A., Mazák, M., \& Dobrovič, J. (2018). Quantitative analysis of the competitiveness of Benelux countries. Entrepreneurship and Sustainability Issues 5(4): 1069-1083. http://doi.org/10.9770/jesi.2018.5.4(26) 

capability

Novikov, S., Amirova, E., Kosykh, E., Chudinovskikh, M., \& Nikolaevskaya, O. (2019). Strategic planning and management of high-tech developments and innovative technical solutions. Research in World Economy, 10(3), 309-314. doi:10.5430/rwe. v10n3p309

Peng, D. X., Schroeder, R. G., \& Shah, R. (2008). Linking routines to operations capabilities: A new perspective. Journal of operations management, 26(6), 730-748.

Rocha, L. A., Dal Poz, M. E., de Almeida, C. A. S., \& de Oliveira, D. M. (2015). O Impacto dos esforços inovativos no desempenho econômico-financeiro das empresas. RAI Revista de Administração e Inovação, 12(3), 82-108.

Rosenbaum, E. (2011), "Competitiveness rankings of European countries - how much do they tell us?”, Intereconomics, Vol. 46 No. 2, pp. 82-90, doi: 10.1007/s10272-011-0368-5.

Sala-i-Martïn, X., Bilbao-Osorio, B., Blanke, J., Hanouz, M.D., Geiger, T. and Ko, C. (2014), "The global competitiveness index 2014-2015: accelerating a robust recovery to create productive jobs and support inclusive growth", in Schwab, K. (Ed.), The Global Competitiveness Report 2014-2015: Full Data Edition, World Economic Forum, Geneva, pp. 3-52.

Spescha, A., \& Woerter, M. (2019). Innovation and firm growth over the business cycle. Industry and Innovation, 26(3), 321-347.

Tsamadias, C., Pegkas, P., Mamatzakis, E., \& Staikouras, C. (2019). Does R\&D, human capital and FDI matter for TFP in OECD countries? Economics of Innovation and New Technology, 28(4), 386-406.

Yoon, D. (2018). The expected effect analysis for the government R\&D investment of research equipment. Polish Journal of Management Studies, 17.

Wang, E. C., \& Huang, W. (2007). Relative efficiency of R\&D activities: A cross-country study accounting for environmental factors in the DEA approach. Research Policy, 36(2), 260273. 